\title{
Pelatihan Penggunaan Aplikasi GIMP untuk Penyuntingan Gambar Bagi Murid Kelas III dan Kelas V Sekolah Dasar Tarsisius 2
}

\author{
Harya Bima Dirgantara ${ }^{1)}$, Yulius Denny Prabowo' ${ }^{2)}$, Tedi Lesmana Marselino ${ }^{3)}$, Yulia Ery Kurniawati ${ }^{4)}$ \\ Paramaresthi Windriyani ${ }^{5}$, Henri Septanto ${ }^{6}$ \\ 1,2,3,4,5) Informatika, Fakultas Ilmu Komputer dan Desain, Institut Teknologi dan Bisnis Kalbis \\ Jalan Pulomas Selatan Kavling 22, Jakarta Timur 13210 \\ ${ }^{1)}$ Email: harya.dirgantara@kalbis.ac.id, \\ 2)yulius.prabowo@kalbis.ac.id, \\ ${ }^{3)}$ tedi.lesmana@kalbis.ac.id, \\ 4)yulia.kurniawati@kalbis.ac.id, \\ 5) paramaresthi.windriyani@kalbis.ac.id \\ 6) Teknik Informatika, Fakultas Teknik dan Informatika, Universitas Dian Nusantara \\ Jalan Tanjung Duren Barat 2, Nomor 1, Jakarta Barat 11470 \\ ${ }^{6)}$ Email: henri.septanro@undira.ac.id
}

\begin{abstract}
At this time, editing images is one of the things that are often done; for example, when people want to post pictures to their social media accounts. The edited image will be more exciting and have specific effects-one of the applications used for editing images in GIMP. GIMP is a free application and is open source so that it can be used by everyone freely. GIMP has certain features that can give effects and beautify the image to be edited. In this counselling activity, SD Tarsisius 2 students were taught to edit images using the GIMP application. With this counselling, it is hoped that they can add to their knowledge and skills in editing images.
\end{abstract}

Keywords: editing images, exciting, GIMP

\begin{abstract}
Abstrak: Pada masa ini menyunting gambar merupakan salah satu hal yang sering dilakukan, contohnya adalah ketika orang ingin memposting gambar ke akun media sosialnya. Gambar yang disunting akan menjadi lebih menarik dan memiliki efek-efek tertentu. Salah satu aplikasi yang digunakan untuk menyunting gambar adalah GIMP. GIMP adalah aplikasi bebas dan merupakan open source sehingga bisa digunakan oleh semua orang dengan bebas. GIMP memiliki fitur-fitur tertentu yang dapat memberikan efek dan memperindah gambar yang akan disunting. Pada kegiatan penyuluhan ini, murid SD Tarsisius 2 diajarkan untuk menyunting gambar menggunakan aplikasi GIMP. Dengan adanya penyuluhan ini diharapkan dapat menambah wawasan dan keterampilan mereka dalam menyunting gambar.
\end{abstract}

Kata kunci: menyunting gambar, menarik, GIMP

\section{PENDAHULUAN}

Sekolah Dasar (SD) Tarsisius 2 berlokasi di kompleks persekolahan Unit Tarsisius 2 di Jl. Batusari Raya No. 12, Kebon Jeruk - Jakarta Barat. Berdiri sejak tahun 1989 (Sekolah, 2018). Dengan status Akreditasi " DISAMAKAN", di samping mempunyai kewenangan untuk menyelenggarakan pendidikan sendiri, SD Tarsisius 2 diberi kepercayaan untuk mengadakan ujian secara mandiri. Selain itu SD Tarsisius 2 mendapat pengakuan sebagai sekolah Katolik dari Majelis Pendidikan Katolik (MPK). Murid kelas III dan kelas V SD Tarsisius 2 cukup mahir menggunakan komputer. Namun, karena keterbatasan materi pembelajaran computer, mereka belum mengetahui tentang aplikasi GIMP. Sehingga dengan adanya pelatihan ini dapat menambah wawasan dan keterampilan mereka dalam menyunting gambar.0020

Pelatihan diselenggarakan selama satu hari di SD Tarsisius 2, pada tanggal 11-12 Februari 2019, pukul 8.00 sampai 16.00 WIB dengan menggunakan ruang Laboratorium Komputer SD Tarsisius 2. Secara umum masalah yang dihadapi mereka adalah keterbatasan materi pembelajaran komputer. Dengan mempelajari GIMP diharapkan dapat menambah variasi materi pembelajaran komputer bagi murid kelas III dan kelas V SD Tarsisius 2.

SD Tarsisius 2 menempati gedung milik sendiri yang dilengkapi ruang-ruang kelas yang nyaman. 
Tersedia juga kapel, laboratorium komputer, ruang serba guna, Ruang UKS, Usaha kesehatan Gigi Sekolah (UKGS). Perpustakaan, lapangan olahraga, toko sekolah dan kantin.

Dengan menggunakan GIMP yang merupakan aplikasi bebas (Slamet et al., 2020)(Pramono, 2004) dapat memberikan peningkatan ketrampilan bagi pengajar (dosen maupun guru) dan dapat juga untuk membuat media pembelajaran berbantuan komputer (Riyadi et al., 2016). Aplikasi GIMP dapat digunakan untuk melukis gambar secara digital (Jamion et al., 2020) maupun menyuntingnya. Murid kelas III dan kelas $\mathrm{V}$ sebagai peserta juga diharapkan dapat menyalurkan bakatnya dalam seni menyunting gambar sejak dini, sehingga bisa meningkatkan kreativitas sejak dini (Asmawati, 2013).

Hasil gambar yang dibuat atau disunting menggunakan GIMP dapat diaplikasikan menjadi karya poster, aset karakter/lingkungan game (Dirgantara et al., 2019), lukisan, atau pun beberapa karya lainnya.

\section{METODE PELAKSANAAN}

Pelatihan sejenis ini telah dilaksanakan berulang kali oleh tim PKM dengan materi yang berbeda, antara lain pelatihan pembuatan game (Dirgantara et al., 2020). Pada pelatihan ini materinya adalah pembuatan/penyuntingan gambar.

\section{A. Perencanaan Kegiatan PKM}

Rencana ini didiskusikan dalam rapat Tim Dosen Program Studi Informatika Fakultas Industri Kreatif Institut Teknologi dan Bisnis Kalbis (Kalbis Institute) yang tergabung ke dalam Tim Pengabdian Kepada Masyarakat (PKM) pada 14 September 2018 jam 08.00 - 17.00 WIB di ruang rapat dosen Lantai 2 Kampus Institut Teknologi dan Bisnis Kalbis (Kalbis Institute) Jalan Pulomas Selatan Kav.22 Jakarta Timur. Diskusi ini untuk membicarakan PKM yang merupakan salah satu wujud Tri Dharma Perguruan Tinggi. Hasilnya adalah kesepakatan untuk melakukan PKM dengan mitra siswa/i SD Tarsisius 2 Jakarta Barat.

Kegiatan observasi tim PKM ke SD Tarsisius 2 Jakarta Barat dilakukan pada tanggal 17 September 2018 oleh Tim Dosen Program Studi Informatika Institut Teknologi dan Bisnis Kalbis (Kalbis Institute) yang tergabung dalam Tim Pengabdian Kepada Masyarakat. Tim PKM disambut oleh Ibu Cecilia Estiarini. Pada pertemuan ini dilakukan pembicaraan awal dan perkenalan antara tim PKM Kalbis dengan mitra SD Tarsisius 2 Jakarta Barat. Tujuan diadakannya observasi awal adalah untuk menggali kembali persoalan serta kebutuhan para siswa/i SD Tarsisius 2 Jakarta Barat.

Pada observasi lanjut tanggal 18 September 2018 di SD Tarsisius 2 Jakarta Barat dibicarakan program dan tema PKM yang diberikan bagi para siswa/i SD Tarsisius 2 Jakarta Barat. Hasilnya adalah kesepakatan untuk mengadakan PKM pelatihan penyuntingan gambar menggunakan GIMP pada tanggal 11-12 Februari 2019 yang bertempat di Laboratorium Komputer SD Tarsisius 2 Jakarta Barat.

Penawaran kerjasama tim PKM kepada mitra disambut dengan baik oleh kepala sekolah dan para siswa SD Tarsisius 2 Jakarta Barat. Mereka sangat mendukung untuk dilaksanakannya kegiatan PKM yang berbentuk pelatihan untuk para siswa SD Tarsisius 2 Jakarta Barat. Kesediaan bekerja sama disampaikan pada saat observasi lanjut yang dilaksanakan pada tanggal 18 September 2018.

\section{B. Pelaksanaan Kegiatan}

Kegiatan pelatihan dilaksanakan pada hari Senin dan Selasa tanggal 11 - 12 Februari 2019 pada pukul 8.00-16.00 WIB di Laboratorium Komputer SD Tarsisius 2. Pelatihan diberikan oleh Tim PKM dari Prodi Informatika yang berjumlah sebanyak 4 orang. Peserta pelatihan adalah para siswa SD Tarsisius 2 Jakarta Barat.

Jam 08.00-08.10 WIB, acara dibuka oleh Bapak Yulius Denny Prabowo, S.T., M.T.I., selaku Ketua Program Studi Informatika Kalbis Institute. Jam 08.10-09.15 WIB acara dilanjutkan dengan sesi pengantar GIMP, materi pelatihan diberikan oleh Bapak Harya Bima Dirgantara, S.Kom., M.T.I.

Jam 09.15-10.15 WIB acara dilanjutkan dengan sesi materi paint tools menggunakan GIMP yang diberikan oleh Ibu Yulia Ery Kurniawati, S.Kom., M.Eng. Jam 10.30-12.00 WIB acara dilanjutkan dengan sesi praktek langsung paint tools lanjutan menggunakan GIMP yang diberikan oleh Ibu Paramaresthi, S.Kom., M.Eng. dan Bapak Harya Bima Dirgantara, S. Kom., M.T.I.

Jam 13.00-14.15 WIB acara dilanjutkan dengan sesi materi color tools menggunakan GIMP yang diberikan oleh Bapak Yulius Denny Prabowo, S.T., M.T.I. Jam 14.30-16.00 WIB acara dilanjutkan dengan sesi praktik secara langsung color tools lanjutan menggunakan GIMP yang diberikan oleh Bapak Yulius Denny Prabowo, S.T., M.T.I. dan Bapak Henri Septanto, S. Kom., M. Kom. 


\section{HASIL DAN PEMBAHASAN}

Kegiatan pelatihan berjalan dengan lancar dan peserta sangat antusias mengikuti pelatihan.

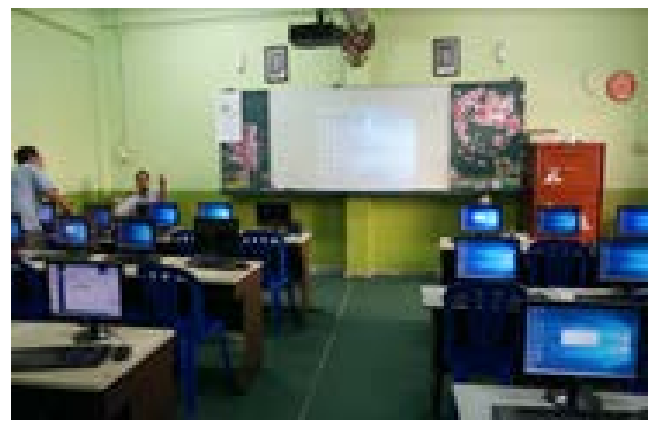

Gambar 1. Persiapan acara

Gambar 1 menampilkan persiapan komputer dan proyektor sebelum acara dimulai.

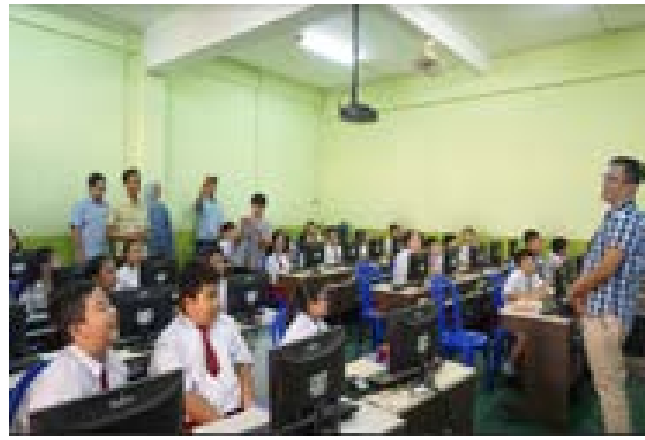

Gambar 2. Pemberian materi

Gambar 2 menampilkan pemberian materi oleh bapak Tedi Lesmana Marselino dan didampingi oleh tim PKM.

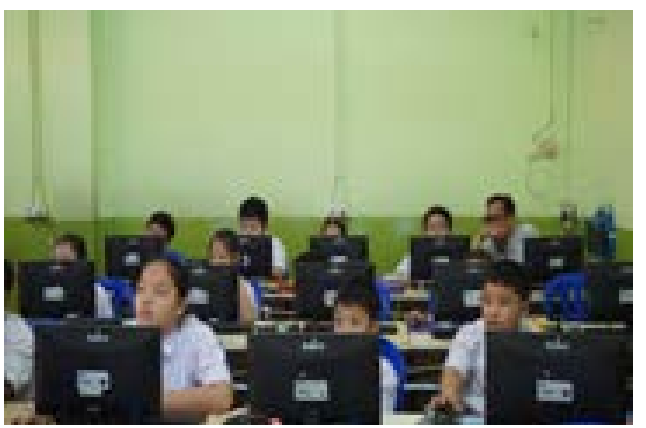

Gambar 3. Peserta antusias

Gambar 3 menampilkan peserta memperhatikan materi yang disampaikan oleh tim PKM.

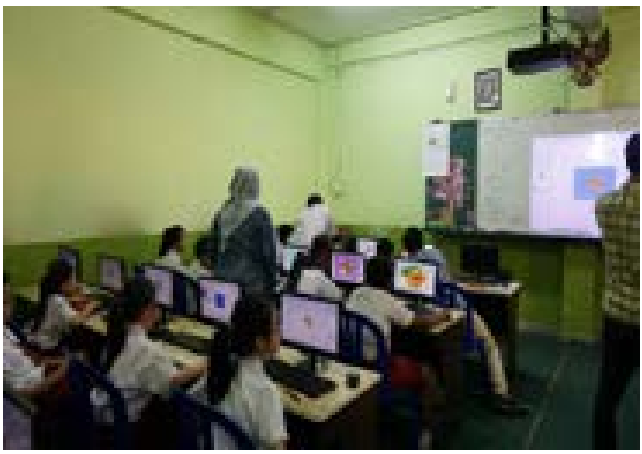

Gambar 4. Peserta praktek
Gambar 4 menampilkan para peserta mencoba mengikuti petunjuk yang diberikan.

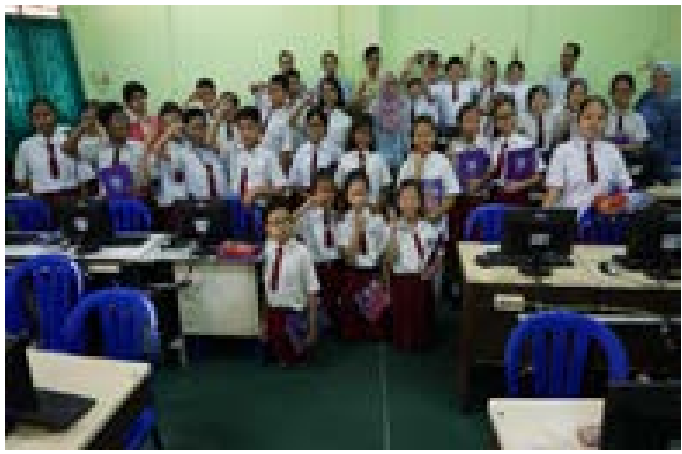

Gambar 5. Penutupan acara

Gambar 5 menampilkan penutupan pelatihan disertai dengan pemberian kenang-kenangan.

\section{SIMPULAN}

Sehubungan dengan uraian di atas, dapat disimpulkan bahwa kegiatan pelatihan yang telah dilakukan pada tanggal 11 - 12 Februari 2019 adalah: (1). Para siswa SD Tarsisius 2 terlihat sangat antusias mengikuti materi yang diberikan oleh para instruktur; (2). Suasana pada saat pelatihan sangat aktif, dimana para siswa memiliki keingintahuan yang begitu besar terhadap tiap materi yang diberikan; (3). Pelatihan yang diberikan membantu para siswa dalam mengenal aplikasi GIMP secara dasar dan lanjut.

\section{DAFTAR RUJUKAN}

Asmawati, L. (2013). Enhancement of Drawing Creativity Through. Jurnal Teknologi Pendidikan, 17(1), 547561.

Dirgantara, H. B., Prabowo, Y. D., \& Jermia, M. M. (2019). Development of android-based quiz video game: Mathventure. Proceedings - International Joint Conference on Information, Media, and Engineering, IJCIME 2019, 450-454. https://doi.org/10.1109/ IJCIME49369.2019.00097

Dirgantara, H. B., Prabowo, Y. D., Kurniawati, Y. E., Windriyani, P., Septanto, H., \& Marselino, T. L. (2020). Pelatihan Pengenalan Game Maker Studio dan. Kalbisabdimas, 3(10), 45-47.

Jamion, F. N. M., Salleh, N. S. M., \& Hussin, R. (2020). pembinaan modul pembelajaran teknik lukisan digital tingkatan tiga. Journal of Applied Arts, 2(1), 141-145.

Pramono, G. (2004). Penggunaan Software Bebas ( Gnu / Linux ) Dalam Pendidikan. Jurnal Teknologi Pendidikan, VIII(15), 5-33.

Riyadi, S., Qamar, K., \& Wulandari, T. C. (2016). Pembuatan Media Pembelajaran Berbantuan Komputer 
Menggunakan Aplikasi Open Source. Seminar Nasional Dan Gelar Produk SENASPRO 2016, 143-147. http:// research-report.umm.ac.id/index.php/research-report/ article/download/765/940

Sekolah, T. 2. (2018). Sejarah Sekolah Tarsisius 2. Web Page. https://www.tarsisius2.sch.id/sejarah/

Slamet, T. I., Alfiansyah, A., Al Maki, W. F., Musyafa, F. A.,
Satyaputra, A., Fathoni, P., Andayani, S. S., Melinda, S., Oktavianus, D., \& Yusuf, N. P. (2020). Peningkatan Keterampilan ICT untuk Guru melalui Pelatihan Konten Digital Pembelajaran Berbasis Sumber Terbuka (Open Sources). Aksiologiya: Jurnal Pengabdian Kepada Masyarakat, 4(1), 118. https://doi.org/10.30651/aks. v4i1.2316 